\title{
Contributing factors on students' willingness to communicate (WTC)
}

\section{Elis Susanti}

Universitas Muhamamdiyah Kotabumi, Jl. Hasan Kepala Ratu No.1052, Sindang Sari, Kotabumi, Kabupaten Lampung Utara, Lampung 34517, Indonesia weasley.ndha@yahoo.com

\section{ARTICLE INFO}

\section{Article history}

Received 14 December 2019

Revised 9 March 2020

Accepted 15 August 2020

Available Online 15 January 2021

\section{Keywords}

willingness to communicate (WTC)

speaking

psychological readiness

L2 performance

anxiety

\section{ABSTRACT}

One of the non-linguistics factors which is sometimes out of the teacher's awareness during the teaching of speaking is how ready or how willing the language learners are to engage in the provided activities in which this psychological condition is then termed as Willingness to Communicate (WTC). To prepare the language learners in order to be more ready or willing is essential to take into account since a fact shows that the high WTC will increase the language learners' frequency of using the language learned (English) in a communication. This is a descriptive qualitative research which investigated about the students' WTC in a speaking class consisting of 29 students English Department in STKIP Muhammadiyah Kotabumi. Apart from this, this study also probed what variables influencing their WTC. An observation was done in order to collect the research data and make a conclusion. Due to the collecting data, it was found that students' WTC is high. Further, some variables such as classroom variables (task type, topic, and interlocutor), individual variables (introversion, self-esteem, and anxiety), and communicative competence are found to contribute on students' WTC during the speaking activity. Among others, the topic given is as the most influential variable affects students' WTC. Whereas, it is found that interlocutor variable due to their gender and age does not affect students' WTC. Hence, English teachers are suggested to give more attention at some variables affecting students' WTC in order to help the students increase their WTC which leads to their speaking improvement.

\section{Introduction}

The success of Foreign Language (FL) acquisition is affected by many factors. Particularly for the speaking skill, the frequency of using the language in communication (students' exposure to the real world) will determine the development of this skill (Ismail, 2011; Shafie \& Nayan, 2010; Pandian, 2002). The more often the students use the language in their real world, the much better improvement of speaking they will achieve. However, many variables or factors affect the students' eagerness to use the language in communication. One of the most variables which have been discussed in many studies is the variable which relates to individual variables such as motivation (Gardner, 2007), self-esteem (Zade \& Hashemi, 2014), self-confidence (Hashimoto, 2002), anxiety (Dewaele et al, 2013; Horwitz et al, 1986; MacIntyre \& Gardner, 1994), and so on. Motivation, self-esteem, self- confidence, anxiety and other individual variables are correlated each other (Adwani \& Shrivastava, 2017). It is for instance, motivated students must have good evaluation or put positive self- worth on themselves, and vice versa (Zoabi, 2012; Alpay, 2000; 
Black \& Wilima, 1998). Those who are motivated also have high self-confidence, and vice versa (Sari et al, 2015; Bénabou \& Tirole, 2001; Karimi \& Saadatmand, 2014). On the other hand, motivation and anxiety is found to be negatively correlated one and another. In a study conducted by Brown et al. in Dornyei \& Schmidt (2001), it is found that lack motivated students will tend to exhibit anxious behaviors.

In this case, it is known that motivation seems to a contributive variable towards others. In a communication, motivation must be able to raise the students' intention to engage in (Adwani \& Shrivastava, 2017) because motivation provides the main impulse to initiate learning second language (L2). At a glance, in this process, it seems that motivation is as the only variable which determines students' activeness in using the language orally. In fact, whether the students eager or not in taking part into communication is firstly influenced by psychological readiness or willingness feeling to communicate (WTC) using the language within the students themselves before the other variables. According to Yashima (2002), "willingness to communicate in second language comes from self- confidence which is affected by one's motivation". In this case, motivation is as a contributive variable which affects students' willingness to communicate indirectly. Here then, it is clear that WTC is the closest variable before motivation which determines students' participation in a communication. Students should have been motivated first, and then they would be willingly engage in a communication. It is in line with a pyramidal model of WTC theory proposes by Dewaele et al. (2013) which places L2 WTC on the top position variable which affects one's L2 use. Meanwhile, motivation is as the variable affecting one's L2 use which is positioned under the L2 WTC.

There have been several studies investigating about the correlation between WTC and some variables in EFL context. First, Manipuspika (2018) investigated about the correlation between anxiety and Willingness to Communicate in the Indonesian EFL Context and found that anxiety positively correlates with students' WTC which means that the anxious students tend to be more apprehensive in making communication using English. The more anxious the students are the more unwilling they are. Additionally, Yousefi \& Kasaian (2014) in their research entitled "Relationship between Willingness to Communicate and Iranian EFL Learner's Speaking Fluency and Accuracy" also found that WTC positively correlates with learners' speaking fluency so that it should be taken into account as an important variable to increase learners' fluency and accuracy in speaking. Referring to the both of previous related studies, it is known that WTC plays an important role in an EFL teaching. It could be considered as an essential contributive variable affecting others' individual variables such as anxiety. Beside, it can also affect students' performance in EFL classroom.

In regard with the findings, this research which will focus on investigating about students' WTC and some contributing factors on the level of students' WTC is hopefully will give additional information which is recommended to increase students' WTC. As the result, it will lead to the improvement of teaching strategy in the classroom speaking.

\subsection{Factors Influencing L2 or FL Acquisition}

Either English is learned as L2 (when the language is used as a means of communication either in an institutional or social context in the community) or FL (when the language is not used as a means of communication in the community but learned as a school subject only), there are several factors which will determine the success of students' L2 or FL acquisition. As Dörnyei (2009) states that the success of L2 or FL acquisition is determined by at least three factors: (1) Contextual factors; (2) Situational factors; and (3) Individual factors. First, contextual factors relates with some contextual reasons like the status of the language learned (whether it is learned as L2 or FL). In the context of English as L2, students have more opportunity to expose the language into their real world rather than those who learn English as FL. As the result, students will be more experienced and skillful to use English in communication. Another contextual factors affecting L2 or FL acquisition is the availability of learning resources. Learning resources must be influential factors affecting the students' success in learning L2 or FL. There should have been supplementary amount of native speakers, relevant books, or even various real world context of interactions which enable the language learners to learn language as natural as possible and enable them to acquire much more contextual knowledge which will help them easier in understanding the use of the language in communication. Second, situational factors are the situation in which it determines types of 
language used in a communication i.e. the level of formality required, the degree of acquaintance with the interlocutor, and so on. Last, individual factors which relate to individual's variable like personality, motivation for learning a FL, age of onset of acquisition, knowledge of other FLs, anxiety and willingness to communicate in a FL, among others.

Adwani \& Shrivastava (2017) point out several factors influencing students' L2 or FL learning success. Those factors are vocabulary, grammar, and interference of mother tongue (L1), selfefficacy and motivation. It seems that the factors consist of the language components factors (vocabulary, and grammar), and individual factors (mother tongue, self- efficacy, and motivation). In this case, the language components which build up the unity of the language should be beneficial to support the acquisition of the language. Meanwhile, students' mother tongue which is often have different structure, pronunciation, collocation, and others related aspect will cause interference in using the language in communication. Further, self-efficacy and motivation psychologically help the students to be ready and willing to use the language in communication.

Both of the theories describe the role of individual factors on students' success in learning L2 or FL which then emphasize the essential of those individual factors to be taken into account in a teaching interaction in order that teacher could set an efficacious classroom interaction for the success of L2 or FL learning. Apart from this, Ismail (2011), Shafie \& Nayan (2010), and Pandian (2002) explain that there are three important factors contributing to the students' failure in mastering English which are education background, exposure to the real world and learning abilities. Specifically with the exposure to the real world factor, it would be predicted by students' WTC which becomes the focus of interest in this research. It is then clarify the importance of investigating students' WTC and the linking factors determining the level of students' WTC.

\subsection{Factors Affecting Students' Willingness to Communicate (WTC)}

WTC as an individual variable affecting students' L2 use in communication is defined as an intention and desire to initiate communication (Riasati, 2018). Meanwhile, MacIntyre (1994) state that WTC is a readiness to get involved in a particular setting of communication. Here then, WTC will determine whether or not the students take part into a communication when the situation comes. In a classroom activity, it is found that the lack of WTC causes an ineffective interactions and language production (Freiermuth \& Jarrell, 2006; Gharibi \& Seyyedrezaei, 2016). Additionally, it is claimed that students with high level of WTC will more often tend to initiate a communication in the classroom so that it increases their amount of oral production (Zade \& Hashemi, 2014; Yashima et al, 2004). It is then clear that student's WTC plays important role in determining their language production especially in oral communication. When the students' language production increases, students' speaking skill will automatically improve due to the more of students' frequency of practicing using the language. Further, besides as an individual variable, WTC is claimed as the primary goal of L2 instruction (Zade \& Hashemi, 2014). It is due to the fact that the focus of a L2 instruction is encouraging the language learners to use the language in effective communication.

Referring to the fact that the primary goal of L2 instruction is to enable the students use the language in an effective communication, it is then essential that the L2 teachers know what factors causing the students reluctant to practice using the language learned (MacIntyre, 2007). Riasati (2018) found that several factors such as task type, seating location, topic of discussion and interlocutor, fear of negative evaluation, fear of correctness of speech, effect of topic discussion, and interlocutor effect as the factors affecting students' level of WTC. Meanwhile, McCroskey \& Richmond (1990) points out several variables contributing to the different level of students' WTC, they are introversion, self-esteem, communication competence, cultural diversity, and communication apprehension. Apart from this, Manipuspika (2018), Rastegar \& Karami (2015), and Muamaroh \& Prihartanti (2013) in their studies found that anxiety is also as a variable correlates negatively with students' WTC. It was found that when students' anxiety is low, students' WTC increases. To sum up, all the factors proposed by those experts are then able to be categorized as follows: (1) classroom variable: task type, seating location, topic of discussion and interlocutor, effect of topic discussion, and interlocutor effect; (2) individual variable: introversion, self- esteem, anxiety (fear of negative evaluation, fear of correctness of speech/communication apprehension); (3) Social variable: cultural diversity; and (4) communication competence variable. 


\section{Research Method}

This research applied a descriptive qualitative research design to investigate students' WTC and the contributing factors on students' WTC. The research subject was the second year students of English department of STKIP Muhammadiyah Kotabumi consisting of 29 students. Observation was done in which the researcher applied a participant observer to collect the research data. Meanwhile, the data was collected using an observation sheet which was constructed on the basis of several variables investigated: (1) classroom variable: task type, seating location, topic of discussion and interlocutor, effect of topic discussion, and interlocutor effect; (2) individual variable: introversion, self- esteem, anxiety (fear of negative evaluation, fear of correctness of speech/communication apprehension); (3) Social variable: cultural diversity; and (4) communication competence variable. The observation sheet checklist consisted of 32 items covering all the variables observed.

\section{Findings and Discussion}

Having collected the data throughout an observation, it is found several results based on the analysis of each variable observed as follows:

\subsection{Classroom Variables}

Specifically for the classroom variables, all related aspects (task type, seating location, topic of discussion, effect of topic discussion) seem to appear to affect students' WTC in the classroom speaking activities, except the interlocutor aspect. Firstly, in relation with the task type given, it is found that students' WTC vary depend on the task type (whether individual, in group, or pairs) given. Students' WTC is high when they should speak up in group either small or larger group as well as in pairs. Whereas, students' WTC were low when students were given a speaking task individually. This is in line with Cetinkaya (2005) in his study which was found that students preferred speak in pairs or group to individually speak in front of the class. Additionally, it is clarified by Cao \& Philip (2006) who stated that working in group or pair would give someone more opportunity to speak up rather than working individually. In this research, it is found that speaking in pairs seem to be the most factors of the classroom variables enhancing students' WTC because all the students are willingly speak up with their pairs in working on the task given.

Secondly, students' seating location affects significantly to the increase of students' willingness to communicate only for several students. It was found that there are only some students whose WTC keep high either sitting in front or in the back row of the classroom. Whereas, there are also some students who keeps quiet without any production of language either sitting in front or in the back row of the class room. Next, topic of discussion affects significantly on the students' WTC. Most of the students tend to engage in the speaking activities when the researcher gave certain topic which made them interested in joining the conversation, as well as the familiar topics they know. They also like to join the speaking activities when the topic is comfortable for them. However, especially for the controversial topics, it was found that there were only some students who participated in the speaking activities for the controversial topics, and the students were those who have high proficiency level of English in class. It is found that students' WTC is high when the topic discussed was familiar, interesting, comfortable, and controversial.

Whereas, this research found that interlocutor does not give influence on the students' WTC due to the different gender and age of the interlocutor. It was found none of the students speak only with the same gender, or speak with those who are older or younger than them. This research reveals that most of the students speak with their friends without seeing their gender, and age and showing high interest to speak up to whomever their interlocutor and with whatever the topic given. Students seem to exhibit the same eagerness and spirit to speak up even though they should discuss a gender oriented topic such as sport with a different gender interlocutor. In this case, this finding is quite different with the finding of Khosravizade \& Pakzadian (2013) which found that students exhibit different WTC level when teacher and students' gender differed due to several certain themes provided in the interview section done by the teacher. Several reasons might be able to clarify this different finding. Another variable of classroom atmosphere like the teacher strategy to grasp the students' attention and interest might be the most reasonable cause for this different finding. As in Kang (2005) and Zarrinabadi (2014) who found that there is teachers' crucial role to create a supportive environment for students by paying attention to the students' knowledge and giving them more power to negotiate topics in which lead them to have high WTC. 
Additionally, Zarrinabadi (2014) also asserted that teachers could enhance students' WTC in classrooms by smiling and responding actively, minimizing their fear of making mistakes and giving more time to them for consideration and reflection before answering questions. To conclude, it is then clear that interlocutor variable could be controlled by the teacher strategy. Teacher should apply effective strategy which enables to keep their students' WTC high whenever they should work on and discuss certain topic with different gender interlocutor.

Lastly, effect of topic discussion and interlocutor seem to affect several students with good language proficiency. This factor does not appear on those with low language proficiency. It is known that those with good competence of language proficiency must be more inclined to initiate communication by asking questions, clarifying, asserting opinion, and so on. However, as stated before that teacher could attempt to raise the low proficiency students' WTC by minimizing their fear of making mistake, minimizing their shy, and maximizing their self-confidence. Therefore, both the high and low proficiency students can have the same opportunity to enhance their WTC.

In conclusion to the classroom variables, several findings seem to be the same as several previous studies findings that classroom variables can be the contributive variables on students' WTC level. However, it is emphasized that teacher also has crucial role to control the classroom atmosphere in attempting to enhance students' WTC. When the teacher is able to create a conducive classroom atmosphere, it is then students will be more willing to engage in the speaking task with no matter the task type given, where they sit, who their interlocutor is, and low or high their language proficiency are.

\subsection{Individual Variables}

Individual variables observed in this research are introversion, self-esteem, anxiety (fear of negative evaluation, fear of correctness of speech/communication apprehension). In this case, there were only several students exhibit the introversion students' characteristics, and those are known to have low WTC. They tend to be quiet and do not actively engage in a speaking activity if the lecturer does not ask them to participate. This finding explains clearly that students' with introversion personality tend to have low WTC. Next, self-esteem and anxiety as individual variable are found to affect students' WTC significantly. Students with good self-esteem also show high WTC in the provided classroom speaking activities. Additionally, those who exhibit anxious behavior tend to be silent and reluctant to speak up. To sum up, this research also reveals the same finding with others related research (Fallah, 2014; MacIntyre \& Gardner, 1994; Peng, 2007); Yashima et al, 2004; Yu et al, 2011) in regard with the influence of individual variables like introversion, self-esteem, anxiety, and so on towards students' WTC.

\subsection{Social variable}

In the social variable, students' cultural diversity does not appear as a variable affects students' WTC. The observation found that those who were reluctant to engage in the speaking activities are due to others variable out of the social variable i.e. students' cultural diversity.

\subsection{Communication competence}

In relation with the communication competence variable, it was found that students with high communication competence are also those who have high WTC. Their good competence makes them ready to engage in a communication. As the result, their WTC is high under any circumstances given by the lecturer.

\section{Conclusion}

Based on the research findings it can be concluded that students' WTC is categorized into high during the teaching and learning process which is seen from several students' behaviors like asking questions frequently, answering lecturer's questions without being pointed, actively commenting on their friends' presentation, and actively joining the class discussion. In relation with some contributing factors on students' WTC, it is found that classroom variables (task type, seating location, topic of discussion, effect of topic discussion), individual variables (introversion, selfesteem, and anxiety), social variable (students' cultural diversity), and the communication competence variables are all affecting variables on students' WTC. Hence, it is important that English teachers and lecturers be more aware of these variables and attempt to facilitate their students to increase their WTC through those variables. 


\section{References}

Adwani, P., and Shrivastava, S. (2017). Analysis of factors affecting second language acquisition. International Journal of Social Science and Management, 4(3), 158-164.

Alpay, E. (2000). Self-concept and self-esteem. London: The Depart- ment of Chemical Engineering and Chemical Technology, Imperial College of Science, Technology, and Medicine.

Bénabou, R., \& Tirole, J. (2001). Self-confidence and personal motivation. Princeton University.

Black, P., \& Wilima, D. (1998). Assessment and classroom learning. Assessment in Education, 5, 7-74.

Brown, J., Robson, G., \& Rosenkjar, P. (1996). Personality, motivation, anxiety, strategies, and language proficiency of Japanese students. In Dornyei, Z., \& Schmidt, R. (Eds.). (2001). Motivation and second language acquisition (pp. 361-398). Honolulu, HI: University of Hawai'i Press.

Cao, Y., \& Philp, J. (2006). Interactional context and willingness to communicate: A comparison of behavior in whole class, group and dyadic interaction. System, 34, 480-493.

Cetinkaya, Y. B. (2005). Turkish college students' willingness to communicate in English as a foreign language. (Unpublished doctoral dissertation). Ohio State University.

Dörnyei, Z. (2009). Personality in second language acquisition. Oxford: Oxford University Press.

Fallah, N. (2014). Willingness to communicate in English, communication self-confidence, motivation, shyness and teacher immediacy among Iranian English-major undergraduates: A structural equation modeling approach. Learning and Individual Differences, 30, 140-147.

Freiermuth, M., \& Jarrell, D. (2006). Willingness to communicate: Can online chat help?. International Journal of Applied Linguistics, 16(2), 189-212.

Gardner, R. C. (2007). Motivation and second language acquisition. PortaLinguarum, 8, 9-20.

Gharibi, S., \& Seyyedrezaei, S.H. (2016). The importance of willingness to communicate and self-esteem in language learning and teaching. JIEB, 4, 194-197.

Hashimoto, Y. (2002). Motivation and willingness to communicate as predictors of reported L2 use: The Japanese ESL context. Second Language Studies, 20(2), 29-70.

Horwitz, E. K., Horwitz, M. B., \& Cope, J. (1986). Foreign language classroom anxiety. The Modern Language Journal, 70(2), 125-132.

Ismail, N. A. (2011). Graduates' characteristics and unemployment: A study among Malaysian graduates. International Journal of Business and Social Science, 2(16), 94-102.

Dewaele, J. M., Comanaru, Ruxandra, S., \& Faraco, M. (2013). The affective benefits of a pre-sessional course at the start of study abroad. Social interaction, identity and language learning during residence abroad, 95-114.

Kang, S.J. (2005). Dynamic emergence of situational willingness to communicate in a second language. System, 33, 277-292.

Karimi, A., \& Saadatmand, Z. (2014). The relationship between self-confidence with achievement based on academic motivation. Kuwait Chapter of Arabian Journal of Business and Management Review, 4(1), 210-215.

Khosravizade, P., \& Pakzadian, S. S. (2013). The relationship between an EFL teacher's gender and students' willingness to communicate. The International Journal of Communication and Linguistic Studies, 10(4), $17-29$.

MacIntyre, P. D. (1994). Variables underlying willingness to communicate: A causal analysis. Communication Research Reports, 12, 241-247.

MacIntyre, P. D. (2007). Willingness to communicate in the second language: Understanding the decision to speak as a volitional process. The Modern Language Journal, 91, 564-576.

MacIntyre, P. D., \& Gardner, R. C. (1994). The subtle effect of language anxiety on cognitive processing in the second language. Language Learning, 44, 283-305. 
Manipuspika, Y. S. (2018). Correlation between anxiety and willingness to communicate in the Indonesian EFL context. Arab World English Journal (AWEJ), 9(2), 200-217.

McCroskey, J. C., \& Richmond, V. P. (1990). Communication, cognition, \& anxiety. A Special Issue of The Journal of The Social Behavior and Personality, 5(2).

Muamaroh, \& Prihartanti, N. (2013). Willingness to communicate in English: A case study of Indonesian university students. Kajian Linguistik dan Sastra Universitas Muhammadiyah Surakarta, 25(1), $71-81$.

Pandian, A. (2002). English language teaching in Malaysia today. Asia-Pacific Journal of Education, 22(2), 35-52.

Peng, J. E. (2007). Willingness to communicate in an L2 and integrative motivation among college students in an intensive English language program in China. University of Sydney Papers in TESOL, 2, 33-59.

Rastegar, M., \& Karami, M. (2015). On the relationship between foreign language classroom anxiety, willingness to communicate and scholastic success among Iranian EFL learners. Theory and Practice in Language Studies, 5(11), 2387-2394.

Riasati, M. J. (2018). Willingness to speak English among foreign language learners: A causal model. Cogent Education.

Sari, I., Ekici, S., Soyer, F., \& Eskiler, E. (2015). Does self-confidence link to motivation? A study in field hockey athletes. Journal of Human Sport \& Exercise, 10(1), 24-35.

Shafie, L. A., \& Nayan, S. (2010). Employability awareness among Malaysian undergraduates. International Journal of Business and Management, 5(8), 119-123.

Yashima, T. (2002). Willingness to communicate in a second language: The Japanese EFL context. The Modern Language Journal, 86(i), 54- 66.

Yashima, T., Zenuk-Nishide, L., \& Shimizu, K. (2004). Influence of attitudes and effect on L2 communication: A study of Japanese high school students. Language Learning, 54(1), 119-152.

Yousefi, M., \& Kasaian, S. A. (2014). Relationship between willingness to communicate and Iranian EFL learner's speaking fluency and accuracy. Journal of Advances in English Language, 2(6), 61-72.

Yu, H., Li, H., \& Gou, X. The personality-based variables and their correlations underlying willingness to communicate. Asian Social Science, 7(3), 253-257.

Zade, M. H., \& Hashemi, A. (2014). Self-esteem, willingness to communicate, and oral production: The case study of Iranian intermediate EFL students. International Journal of Language and Linguistics, 2(4), 290294.

Zarrinabadi, Z. (2014). Communicating in a second language: Investigating the effect of teacher on learners' willingness to communicate. System, 42(1), 288-295.

Zoabi, K. (2012). Self-esteem and motivation for learning among minority students: A comparison between students of pre- academic and regular programs. Creative Education, 3(8). 